\title{
Influence of temperature and leaf wetness duration in the severity of Cercospora leaf spot of beet
}

\author{
Leandro Luiz Marcuzzo ${ }^{1}$, Roberto Haveroth ${ }^{1}$, Aline Nacimento ${ }^{1}$
}

\begin{abstract}
${ }^{1}$ Instituto Federal Catarinense - IFC/Campus Rio do Sul, CP 441, CEP 89.163-356, Rio do Sul, SC.
Autor para correspondência: Leandro Luiz Marcuzzo (marcuzzo@ifc-riodosul.edu.br)

Data de chegada: 07/07/2015. Aceito para publicação em: 09/10/2015.
\end{abstract}

$10.1590 / 0100-5405 / 2111$

\section{ABSTRACT}

Marcuzzo, L.L.; Haveroth, R.; Nascimento, A. Influence of temperature and leaf wetness duration on the severity of Cercospora leaf spot of beet. . Summa Phytopathologica, v.42, n.1, p.89-91, 2016.

In the present study, the influence of temperature $\left(15,20,25,30\right.$ and $\left.35^{\circ} \mathrm{C}\right)$ and leaf wetness period $(6,12,24$ and 48 hours) on the severity of Cercospora leaf spot of beet, caused by Cercospora beticola, was studied under controlled conditions. Lesion density was influenced by temperature and leaf wetness duration $(\mathrm{P}<0.05)$. Data were subjected to nonlinear regression analysis. The generalized beta function was used for fitting the disease severity and temperature data, while a logistic function was chosen to represent the effect of leaf wetness on the severity of Cercospora leaf spot. The response surface resultant of the product of the two functions was expressed as ES $=0.0001105$ $*\left(\left((x-8)^{2.294387}\right) *\left((36-x)^{0.955017}\right)\right) *(0.39219 /(1+25.93072 * \exp (-0.16704 * y)))$, where: ES represents the estimated severity value $(0.1) ; x$, the temperature $\left({ }^{\circ} \mathrm{C}\right)$ and $y$, the leaf wetness duration (hours). This model should be validated under field conditions to assess its use as a computational forecast system for Cercospora leaf spot of beet.

Keywords: Beta vulgaris, Cercospora beticola, epidemiology, plant disease forecasting

\section{RESUMO}

Marcuzzo, L.L.; Haveroth, R.; Nascimento, A. Influência da temperatura e da duração do molhamento foliar na severidade da cercosporiose da beterraba. Summa Phytopathologica, v.42, n.1, p.89-91, 2016.

No presente trabalho foram estudadas, em condições controladas, a influência da temperatura $\left(15,20,25,30\right.$ e $\left.35^{\circ} \mathrm{C}\right)$ e do molhamento foliar $(6$, 12,24 e 48 horas) na severidade da cercosporiose da beterraba causada por Cercospora beticola. A densidade de lesões foi influenciada pela temperatura e pela duração do molhamento foliar $(\mathrm{P}<0,05)$. Os dados foram submetidos à análise de regressão não linear. A função beta generalizada foi usada para ajuste dos dados de severidade e temperatura, enquanto uma função logística foi escolhida para representar o efeito do molhamento foliar na severidade da cercoporiose. A superfície de resposta obtida pelo produto das duas funções foi expressa por $\mathrm{SE}=0,0001105 *\left(\left((x-8)^{2,294387}\right) *\left((36-x)^{0,955017}\right)\right) *(0,39219 /$ $(1+25,93072 * \exp (-0,16704 * y)))$, onde SE, representa o valor da severidade estimada $(0,1) ; x$, a temperatura $\left({ }^{\circ} \mathrm{C}\right)$ e $y$, o molhamento foliar (horas). Este modelo deverá ser validado em condições de campo para aferir o seu emprego como um sistema de previsão computacional para a cercosporiose da beterraba.

Palavras-chave: Beta vulgaris, Cercospora beticola, epidemiologia, previsão de doenças

The main disease affecting beet crop is Cercospora leaf spot, caused by Cercospora beticola Sacc. This disease leads to the leaf blade destruction and consequent yield reduction. Generalized occurrence of this disease may represent a reduction of 15 to $45 \%$ in productivity.

Favorable conditions to this disease are air humidity higher than $90 \%$ and temperatures between 22 and $26{ }^{\circ} \mathrm{C}$. Although chemical control is available, Cercospora leaf spot normally precludes the commercialization of packed plants due to the presence of diseased and senescent leaves $(6,9)$.

Characteristic symptoms are observed in older leaves because they are more susceptible (11). Initially, symptoms are small spots which evolve to circular shapes that can reach 4 to $5 \mathrm{~mm}$. The spots have a light brown center and reddish purple borders. As the lesions increase to become grayish with necrosis, the injured tissue falls and the leaf becomes punctured. The increased area and number of lesions induce senescence and significant reduction in the leaf area. The plant replaces the leaves from tuber reserves, which can cause yield reduction, and this process is repeated several times during the plant growth cycle $(6,9)$.

The establishment of a disease depends on the interaction among environment, host and pathogen. Environmental factors such as temperature and leaf wetness are critical to the epidemiological process. Nowadays, there are mathematical models developed to predict the best conditions for the disease occurrence (2). These models have been used for some plant disease systems such as soybean rust, downy mildew, apple leaf spot and wheat blights (8). Predictive models of plant diseases are simplified representations of the reality and provide the most favorable conditions for the initial or future development of a disease, warning to the time for preventive 


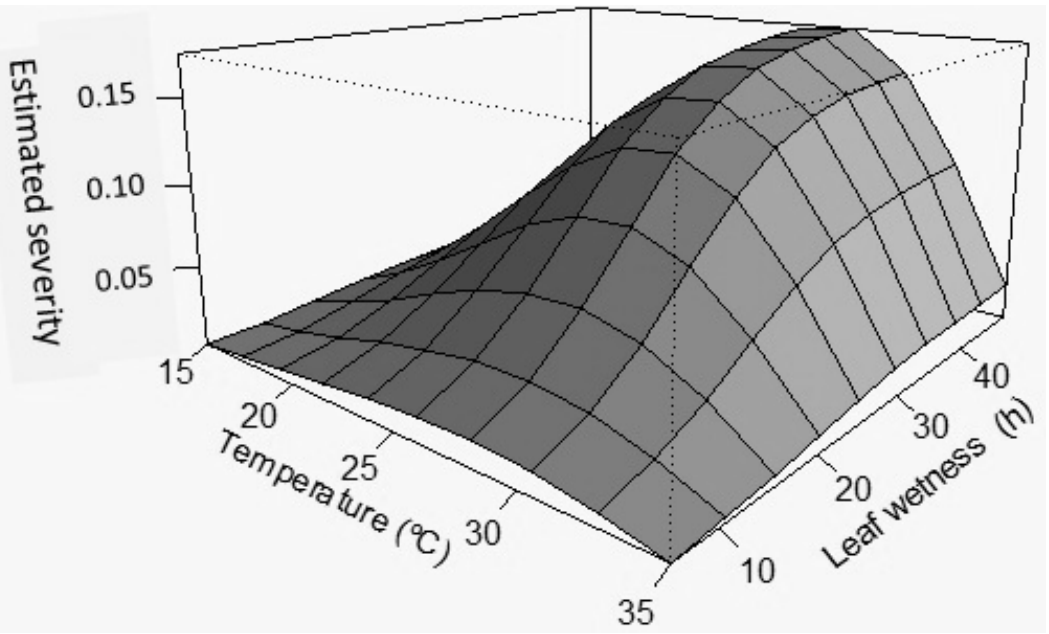

Figure 1. Estimated severity of Cercospora leaf spot (Cercospora beticola) of beet for the cultivar Stays Green, based on the interaction between temperature and leaf wetness represented by ES $=0.0001105 *\left(\left((x-8)^{2.294387}\right) *\left((36-x)^{0.955017}\right)\right) *(0.39219 /(1+25.93072 * \exp (-0.16704 * y)))$, where: $\mathrm{ES}=$ estimated severity $(0.1) ; x=$ temperature $\left({ }^{\circ} \mathrm{C}\right) ; y=$ leaf wetness (h). IFC/ Rio do Sul Campus, 2015.

control application (1).

The aim of this study was to establish the relationship between different temperature values and leaf wetness duration on the severity of Cercospora leaf spot of beet.

This study was conducted at the Federal Institute of Santa Catarina - IFC / Rio do Sul Campus, SC. Beet seeds of the Green Stays cultivar were sown in $300-\mathrm{mL}$ pots containing substrate mixture and nonsterile soil.

After 50 days, when the plants had three expanded leaves, they were inoculated with a spore suspension of Cercopora beticola cultivated for seven days on tomato extract medium ( $200 \mathrm{ml}$ of tomato extract, 3 $\mathrm{g}$ of $\mathrm{CaCO}_{3}, 20 \mathrm{~g}$ of agar and $1.000 \mathrm{~mL}$ of distilled water) in Neubauer chamber at a concentration of $1 \times 10^{4}$ spores/mL by spray method until runoff with a manual atomizer. After inoculation, the plants were placed on a plastic tray containing one centimeter of non-sterile water to maintain the moisture and were packed in a clean moistened plastic bag. To keep the relative humidity above $90 \%$, a nebulizer was connected to the bag. The trays were transferred to BODs, the temperature was adjusted to $15,20,25,30$ and $35^{\circ} \mathrm{C}$ with 12-hour photoperiod and the plants were kept for 6, 12, 24 and 48 hours under constant moisture. At the end of each wetness period, the plants were dried with heated forced air and transferred to $25^{\circ} \mathrm{C}\left( \pm 1^{\circ} \mathrm{C}\right)$. Disease severity was assessed based on the percentage of severity in the three leaves on the fourteenth day after inoculation according to the diagrammatic scale proposed by May de Mio et al. (5).

A completely randomized design with three replicates was used for each combination between temperature and wetness, and each replicate consisted of one plant.

The average of the severity values of three inoculated leaves was used to determine the relationship between leaf wetness duration and temperature for the disease severity.

The response surface is a result of the product of two functions. The generalized beta function was used to determine the severity of the response to different temperatures and was expressed by the equation $\mathrm{y}=\mathrm{b} 1 *(\mathrm{~T}-\mathrm{b} 2)^{\mathrm{b} 4 *}(\mathrm{~b} 3-\mathrm{T})^{\mathrm{b} 5}$, where $\mathrm{b} 2$ is the minimum temperature parameter estimator; the estimator parameter $b 3$ is the maximum temperature; b1, b4 and b5 are parameters of the equation; $\mathrm{T}$ is the independent variant, which in this case is the temperature; and $y$ is the estimated severity. The beta generalized function used to model the effect of temperature on the severity expresses the boundary between the maximum and the minimum temperatures by the introduction of the proposed parameters in the model and demonstrates that the temperature increase directly affects the disease development until a specific limit is reached, after which there is a sharp decrease (3).

The logistic function expressed by the equation: $y=y m a x /(1+\exp (-$ $\ln \left(\mathrm{yo} /(\mathrm{ymax}-\mathrm{yo})-\mathrm{r}^{*} \mathrm{x}\right)$ is used to correlate with the severity leaf wetness duration, where $y$ is the predicted severity, ymax is the maximum disease severity, $\ln$ (yo / (ymax-yo) refers to the function of the disease proportion in the first observation, $\mathrm{r}$ corresponds to the rate and $\mathrm{x}$ is the time of wetness. This function represents the leaf wetness and the severity since the increase in the number of leaf wetness hours leads to a raise in the disease severity if there are favorable temperature conditions (10).

The formula $\mathrm{ES}=0.0001105 *\left(\left((x-8)^{2.294387}\right) *\left((36-x)^{0.955017}\right)\right) *$ $(0.39219 /(1+25.93072 * \exp (-0.16704 * y)))$, where ES represents the value of the estimated severity $(0,1)$; $x$, the temperature $\left({ }^{\circ} \mathrm{C}\right)$, and $y$, the wetness time, which was established as an appropriate mathematical model to represent the response surface (Figure 1).

A gradual raise in the disease was noted when the temperature increased from 25 to $30^{\circ} \mathrm{C}$ for a period of continuous leaf wetness. The collected data do not match the literature that describes the ideal disease development from 22 to $26^{\circ} \mathrm{C}(4,9)$. Racca \& Jörg (7), evaluating the effect of temperature on the sporulation of $C$. beticola, found that the highest temperature was $30^{\circ} \mathrm{C}$; on the other hand, when the temperature changed from 30 to $35^{\circ} \mathrm{C}$, there was a reduction in sporulation. Although that study is not about severity, it can be used as a parameter for disease development. However, this reference does not describe a mathematical model to explain the effect. In this paper, in the interval between 15 and $20^{\circ} \mathrm{C}$, there was a sharp increase in severity when the leaf wetness period exceeded 10 hours. However, at $35^{\circ} \mathrm{C}$ symptoms were present, even after 40 hours of wetness.

The information obtained from the interaction between temperature and leaf wetness allows better understanding of the epidemiology of this disease and can be used to compose a weather model for computerized forecasting of Cercospora leaf spot of beet. 


\section{REFERENCES}

1. Barreto, M.; Vale, F.X.R.; Paul, P.A.; Scaloppi, E.A.G.; Andrade, D.F.A Sistemas de previsão e estação de aviso. In: Vale, F.X.R.; Jesus Junior, W.C.; Zambolim, L. Epidemiologia aplicada ao manejo de doenças de plantas. Belo Horizonte: Perffil, 2004. p.243-266.

2. Bergamim Filho, A.; Amorim, L. Doenças de plantas tropicais: epidemiologia e controle econômico. São Paulo:Ceres, 1996. 299p.

3. Hau, B. Analytic modes of plant disease in a changing environmental. Annual Review of Phytopathology, Palo Alto, v.28, p. 221-245, 1990.

4. Hermann, O. Reconnaître les maladies foliaires de la betterave au champ. Institut Royal Belgepourl'Amérlioration de la Betterave (IRBAB/ KBIVB), 1998. Disponível em: $<\mathrm{http}: / / w w w$.irbab-kbivb.be/.../GuideMaladiesFoliaires.pdf>. Acesso em: 28 de mai. 2014.

5. May de Mio, L.L.; Oliveira, R.A.; Floriani, A.M.V.; Schuber, J.M.; Poltronieri, A.S.; Araujo, M.A.; Tratch, R. Proposta de escala diagramática para quantificação da cercosporiose da beterraba. Scientia Agraria, Curitiba, v.9, n.3, p.331-337, 2008.

6. Puiatti, M.; Finger, F.L. Cultura da beterraba. In: Fontes, P.C.R. Olericultura: teoria e prática. Viçosa: Suprema, p.345-354, 2005.

7. Racca, P.; Jörg, E. CERCBET 3 - a forecaster for epidemic development of Cercospora beticola. Bulletin OEPP/EPPO Bulletin, v.37, p.344-349, 2007.

8. Reis, E.M. Previsão de doenças de plantas. Passo Fundo:UPF, 2004. 316p.

9. Tivelli, S.W.; Factor, T.L.; Teramoto, J.R.S.; Fahi, E.G.; Moraes, A.R.A.; Trani, P.E.; May, A. Beterraba, do plantio à comercialização. Série Tecnologia APTA. Boletim Técnico IAC, 210. Campinas: Instituto Agronômico, 2011. 45p.

10. Vale, F.X.R.; Zambolim, L. Influência da temperatura e da umidade nas epidemias de doenças de planta. Revisão Anual de Patologia de Plantas, Passo Fundo, v.4, p.149-207, 1996.

11. Weiland, J.; Koch, G, Sugarbeet leaf spot disease (Cercospora beticola Sacc.). Molecular Plant Pathology, London, v.5, n.3, p.157-166, 2004 